\title{
Can Dietary Manipulation Cure Crohn's Disease?
}

\author{
Gilles RG Monif* \\ Infectious Diseases Incorporated, Georgia
}

Submission: January 23, 2020; Published: February 21, 2020

*Corresponding author: Gilles RG Monif, Infectious Diseases Incorporated, is 17121 Lakewood Drive Bellevue Nebraska 68123, Georgia

\begin{abstract}
In isolated cases of Crohn's disease, dietary manipulations have produced what biologics and steroids have yet to document, permanent remissions/cures. The postulate introduced is that permanent remissions achieved through dietary manipulation are achieved by marked reduction of MAP antigen/pre-primed antibody interactions and by dietary immune system restoration/enhancement that may result in the destruction of the MAP-template driving the dysfunctional pro-inflammatory immune response.

Keywords: Crohn's disease; Dietary manipulations; Mycobacterium avium; Gastrointestinal microbiota; Zinc deficiencies; Antioxidant effect; Vitamin C; Minerals; Amino acids
\end{abstract}

\section{Crohn's Disease is a Zoonotic Food-Borne Disease}

Mycobacterium avium subspecies paratuberculosis (MAP) is a significant pathogen for milk-producing domestic animals. Infected animals have the ability to shed the mycobacterium into their milk [1,2]. MAP survives pasteurization [3,4]. USDA's failure to address the growing prevalence of MAP in dairy herds has resulted in widespread dissemination of the mycobacterium particularly within milk-based food products [5]. MAP has been identified in infant formula, powdered milk, milk, cheese, etc [6-13].

In contrast to their pathogenicity as replication pathogens in domestic animals, MAP and other atypical mycobacteria have limited pathogenicity for humans unless congenital or acquire immunodeficiency is present $[14,15]$. At birth, newborn infants lacking acquired immunity are analogous to a germ-free animal. Acquired immunity is central to establishing immunological governance over viral and mycobacterial infections. The Hruska postulate introduced the concept that, if a newborn becomes infected with MAP in its period of immunological vulnerability, the ability of its inherent immune system to abort mycobacterial replication could be severely challenged [16]. Depending on the baby's genetic profile, the magnitude of the infectious MAP inoculum, and the status of its developing acquired immunity, the baby's inherent immune system can become so taxed that its TH1 pro-inflammatory response to MAP becomes fixed within immunological memory. Whenever the body is again presented with MAP's antigenic array, rather than responding by exhibiting immunological tolerance, immunity re-initiates it's original pro-inflammatory cytokine responses and attacks MAP at its site of attachment and antigen processing. Fecal stasis concentrates MAP challenges in the ileoce cum. The focal destruction of the gastrointestinal mucosa allows for penetration of the gastrointestinal microbiota into the lamina propria and underlying tissues $[17,18]$.

\section{Dietary Exclusion Therapeutic}

Things happen for a reason. Isolated unstructured observations without implied mechanism of action are rarely published in the medical literature. Most cases of permanent resolution of Crohn's disease through dietary manipulation are found in the lay literature. What is in the medical literature is the demonstration that dietary use of specific carbohydrates (the SCD diet) can produce demonstrable clinical amelioration in cases of pediatric Crohn's disease $[19,20]$. While the SCD diet improved mucosal inflammation, healing could not be documented [21,22].

Central to re-establishing mucosal integrity is aborting antigen/ antibody cytotoxicity at MAP's sites of mucosal attachment. The pathogenesis of Crohn's disease argues for the removal from diet of all foods that have the potential of having been adulterated by MAP, more specifically all dairy based products and red meat. By so doing, the number of cytotoxic antigen/antibody interactions within the gastrointestinal tracts are markedly reduced. Biologics act by dismantling the cytotoxic cytokine response to MAP. Dietary exclusions utilize prevention of, rather than immune response interference to achieve the same objective, reconstitution 
of mucosal integrity. Being nearly impossible to identify and/or eliminate all MAP adulterated foods, dietary exclusion and biologics are complementary to each other in re-establishing mucosal reconstitution.

\section{Dietary Supplementation Therapeutics}

How individual dietary constituents influence host immunity is well documented in the medical literature. In Crohn's disease, the induced alterations of gastrointestinal structure and function compromise the quantitative availability of vitamins, minerals and selected amino acids essential to effective immune system function.

\section{Minerals}

Zinc is a prime example of how deficiency of a single mineral can undermine immune system integrity. The body has no specialized system to store zinc [23]. Individuals with Crohn's disease will have zinc deficiency impairment affecting a broad spectrum of immune mechanisms owing to decreased absorption and in creased exogenous loss [24]. Individuals with a diarrheal disease will have high fecal loss. Zinc is important to the catalytic activity of approximately 100 enzymes involved with immune system function and DNA synthesis [25]. Zinc deficiencies result in adverse changes in cytokine production and T-cell subpopulations [26]. A side effect of zinc deficiency is anorexia which in itself can create a negative feedback.

\section{Vitamin}

The vitamin $\mathrm{C}$ and $\mathrm{E}$ interactions are central to immune system maintenance. Vitamin $\mathrm{C}$ regenerates vitamin $\mathrm{E}$ from its oxidized form. The lipid soluble antioxidant vitamin E not only protects the integrity of cell membranes, but functions synergistically with other nutritional elements that beneficially influence cell-mediated immunity. The salvage of vitamin $\mathrm{E}$ influences the immune functions of selenium which in turn has a beneficial impact on copper and zinc utilization.

Like zinc, vitamin $\mathrm{C}$ has limited storage within the human body. Through its antioxidant effect, vitamin C plays a central role in the containment of mycobacteria [27]. The body's need for vitamin C dramatically increases with infection/disease [28].

\section{Destruction of the Map Immune Template}

The reason for acute therapeutic focus on vitamins, minerals, and amino acids central to maintenance of optimal host immunity is the postulate that the curing of Crohn's disease is contingent upon destruction of the MAP templates (spheroplasts) sustaining the dysfunctional immune response that is characteristic of Crohn's disease.

The evidence relating to destruction of the MAP template through specific enhancement of host immunity is derived in part from a four-month study of a cow with near terminal Johne's disease. In an attempt to prolong her life in order to collect high-ti- ter anti-MAP serum, a specialized diet was designed that targeted enhancement of cellular immunity. When finally necropsied four months later, the cow had regained all her body weight. The serological markers for MAP infection had dropped to near normal status. No gross or histological evidence of Johne's disease could be identified [29]. Evidence of acid-fast bacilli in diseased tissue was totally absent. What was present was a clue as to how the body can actually destroy mycobacteria [30]. The significance of this observation, which was supported by field trials in diseased animals, provided insight as to how dietary manipulation had, more likely than not, attained permanent remissions [31].

A secondary substantiation of MAP spheroplasts driving the dysfunctional proinflammatory immune-mediate response comes from the only other therapeutic regimen that has produced isolated cures of Crohn's disease: anti-mycobacterium drugs [3237]. As a general rule, anti-tuberculosis drugs have not produced cures. When they have, the mechanism of action of one or more of the compounds used involved disruption of RNA function. For an antibiotic to destroy bacteria without a cell wall (spheroplasts), the drug must act on the organism's ribosomes.

\section{Why Dietary Manipulation Can Fail}

Crohn's disease is the consequence of two inter-related but separate disease processes; a dysfunctional immune-mediated response to MAP's antigen array and polymicrobial bacterial invasion of small bowel by the gastrointestinal microbiota [38]. Failure to appropriately negate the latter through comprehensive antibiotic therapy will produce the late sequela of Crohn's disease: strictures, loop-to-loop anastomoses, peri-anal fistula, bowel perforations, etc. [39-40]. Once in place, the curing of Crohn's disease may require surgical intervention.

\section{Dietary Maipulation's Risk-Benefit Ratio}

To date, there is still no test that distinguishes human MAP infection from Crohn's disease. Delay in commitment to therapy enhances the potential for structural damage to the ileocecum. Dietary manipulation is a therapeutic tool with literally no indefinable adverse consequence whose end-titration point is contended to be cure destruction of the MAP templates.

\section{References}

1. Millar D, Ford, J Sanderson J (1996) IS 900 PCR to detect Mycobacterium avium subspecies paratuberculosis in retail supplies of whole pasteurized milk in England and Wales. Appl Environ Microbiol 62: 3446-3454.

2. Grant IR, Ball HJ, Rowe MT (2002) Incidence of Mycobacterium paratuberculosis in bulk raw and commercially pasteurized milk from approved dairy processing establishments in the United Kingdom. Appl Envir Microbiol 68(5): 2428-2435.

3. Pinedo PJ, Williams JE, Monif GRG (2008) Mycobacterium paratuberculosis shedding into milk: association of ELISA seroreactivity with DNA detection in milk. Intern. J Appl Res Vet Med 6: 137-144. 
4. Ellingson JL, Anderson JL, Koziczkowski JJ (2005) Detection of viable Mycobacterium avium subspecies paratuberculosis in retail pasteurized whole milk by two culture methods and PCR. J Food Prot 68(5): 966-972.

5. Monif GRG (2018) Retrospective Assessment of USDA Steward ship of Mycobacterium avium subspecies paratuberculosis dilemma. Paratb Newsletter Jully, p. 4-8.

6. Ayele WY, Svastova P, Roubal P, Bartos M, Pavlik I. et al. (2005) Mycobacterium avium subspecies paratuberculosis cultured from locally and commercially pasteurized cow's milk in the Czech Republic. Appl Envir Microbiol 71(3): 1210-1214.

7. Hruska K, Baros M, Kralik P, Pavlik I (2005) Mycobacterium avium subspecies paratuberculosis in powdered infant milk: paratuberculosis in cattle - the public health problem to be solved. Veterinarni Medicina 50: $327-335$.

8. Botsaris G, Swift BM, Slana I, Liapi M, Christodoulou M, et al. (2016) Detection of viable Mycobacterium avium subspecies paratuberculosis in powdered infant formula by phage-PCR and confirmed by culture. Intern J Food Micriobiol 216: 91-94.

9. Hassan KI, Ali AA (2012) Detection of Mycobacterium avium in infant powdered milk using species specific ROI. Int J Adv Sc Eng Technol 2: 115-119.

10. El-Malek S, Mohamed K (2011) Detection of MAP IS900 in baby milk powder in Egypt. Egypt Int J Microbiol Res 2: 54-60.

11. Clark DL Jr, Anderson JL, Koziczkowski JJ, Ellingson JL (2006) Detection of Mycobacterium avium subspecies paratuberculosis in cheese curds purchased in Wisconsin and Minnesota. Molecular Cell Probes 20(34): 197-202.

12. Ikonomopoulos J, Pavlik I, Bartos M, Svastova P, Ayele WY, et al. (2005) Detection of Mycobacterium avium subspecies paratuberculosis in retail cheese from Greece and Czech Republic. Appl Environ Microbiol 71(12): 8935-9036

13. Hruska K, Slama J, Kralik P, Pavlik I (2011) Mycobacterium avium subsp. paratuberculosis in powdered milk: F57 competitive real time PCR: Veterרinarni Medicina. pp. 226-230.

14. Infectious Diseases Inc.

15. Hellyer TJ, Brown IN, Taylor MB, Allen BW, Easmon CS (1993) Gastrointestinal involvement in Mycobacterium avium-intracellulare infection of patients with HIV. J Infect 26(1): 55-66.

16. Monif GRG (2015) The Hruska postulate of Crohn's disease. Med Hypoth 85(6): 878-881.

17. Monif GRG (2016) Translation of hypotheses to therapy in Crohn's disease. J Inflam Bowel Dis \& Disorder 22(2): E8-9.

18. Monif GRG (2017) An infectious disease process within an immunemediated disease process: Role of the gastrointestinal microbiota in Crohn's disease. Adv Res Gastroenterol Hepatol 5(5): 1-2.

19. Burgis JC, Nguyen K, Park KT, Cox K (2016) Response to strict and liberalizatized specific carbohydrate diet in pediatric Crohn's disease. World J Gastroenterol 22(6): 2111-2117.

20. Suskind DL, Wahbeh G, Cohen SA, Damman CJ, Klein J, et al. (2016) Patients perceive clinical benefit with specific carbohydrate diet for inflammatory bowel disease. Dig Dis Sci 61(1): 325517.

21. Cohen SA, Gold BD, Oliva S, Lewis J, Stallworth A, et al. (2014) Clinical and mucosal improvement with specific carbohydrate diet in pediatric Crohn's Disease. J Pediatr Gastroenterol Nutr 59(4): 516-521.
22. Wahbeh GT, Ward BT, Lee DY, Giefer MJ, Suskind DL (2017) Lack of mucosal healing from modified specific carbohydrate diet in pediatric patients with Crohn's disease. J Paediatr Gastroenterol Nutr 65(3): 289-292.

23. Rink L, Gabriel P (2000) Zinc and the immune system. Proc Nut Soc 59: 541-552.

24. McClain CJ, Soutor C, Zieve L (1980) Zinc deficiency; a complication of Crohn's disease. Gastroenterol 78(2): 272-279.

25. Wintergerst ES, Maggini S, Hiorning DH (2007) Contributions of select vitamins and trace elements immune function. Ann. Nutri Metabol 51(4): 301-323.

26. Prasad AS, Beck FW, Grabowski SM, Kaplan J, Mathog RH (1977) Zinc deficiency: changes in cytokine production and T-cell subpopulations in patients with head and neck cancer and non-cancer patients. Proc Assoc Am Physicians 109(1): 68-77.

27.Wintergerst ES, Maggini S, Horning DH (2006) Immune-enhancing role of vitamin $\mathrm{C}$ and zinc and effect on clinical conditions Ann Nutr Metab 50(2): 85-95.

28. Webb AL, Villamor E (2007) Update: effects of antioxidant and nonantioxidant vitamins on the Immune system. Nutr Rev 65(5): 181-217.

29. Buergelt CD, Williams JE, Monif GRG (2004) Spontaneous clinical remission of Johne's disease in a Holstein cow. Intern. J Appl Res Vet Med 2: 126-128.

30. Monif GRG, Williams JE (2015) Relationship of intestinal eosinophilia and acid-fast bacilli in Johne's disease. Intern J Appl Res Vet Med 13: 147-149.

31. Williams JE, Monif GRG (2008) Impact of immunonutritional dietary additives on AGID positive cows with Johne's disease. Paratb, Newsletter, p. 7-8.

32. Warren J, Rees H, Cox T (1986) Remission of Crohn's disease with tuberculosis therapy. N Engl J Med 314(3): 182.

33. Borody TJ, Bilkey S, Wettstein AR, Leis S, Pang G, et al. (2007) Anti-mycobacterial therapy in Crohn's disease heals mucosa with longitudinal scars. Dig. Liver Dis 39(5): 438-444.

34. Chamberlin W, Ghobrial G, Chehtane M, Naser SA (2007) Successful treatment of a Crohn's disease patient with bacteremic Mycobacterium paratuberculosis. Am J Gastroenterol 102(3): 689-691.

35. Shafran I. Burgeunder P (2008) Rifaximin for the treatment of newly diagnosed Crohn's disease: a case series. Am J Gastroenterol 103(8): 2158-2160.

36. Biroulet IP, Neut C, Colombel JF (2008) Anti-mycobacterium therapy in Crohn's disease: the end of a long controversy? Prac Gastro 1: 11-17.

37. Chamberlin W, Borody TJ, Campbell J (2011) Primary treatment of Crohn's disease: combined antibiotics taking center stage. Expert Rev Clin Immunol 7(6): 751-750.

38. Monif GRG (2017) An infectious disease process within an immunemediated disease process: Role of the gastrointestinal microbiota in Crohn's disease. Adv Res Gastroenterol Hepatol 5(5): 1-2.

39. Monif GRG (2018) Are the permanent sequelae of Crohn's disease a failure to treat the gastrointestinal microbiota? Med Hypothesis 122: 198-199.

40. Monif GRG (2018) Theoretical antibiotic selection for polymicrobial infection in Crohn's disease. Adv. Res Gastroentero Hepatol 10: 1-2. 
This work is licensed under Creative Commons Attribution 4.0 License

DOI: 10.19080/ARGH.2020.14.555896
Your next submission with JuniperPublishers will reach you the below assets

- Quality Editorial service

- Swift Peer Review

- Reprints availability

- E-prints Service

- Manuscript Podcast for convenient understanding

- Global attainment for your research

- Manuscript accessibility in different formats ( Pdf, E-pub, Full Text, audio)

- Unceasing customer service

Track the below URL for one-step submission https://juniperpublishers.com/online-submission.php 